\title{
PENGARUH RETAIL MIX TERHADAP KEPUTUSAN PEMBELIAN KONSUMEN DI DM BARU SWALAYAN BANTUL
}

\author{
Iddam Restu Analde \\ restuiddam@gmail.com \\ Universitas Ahmad Dahlan \\ Sukardi \\ sukardi_feuad@yahoo.com \\ Universitas Ahmad Dahlan
}

\begin{abstract}
ABSTRAK
This study aims to determine (1) whether there is a retail effect mix (Product Diversity, Store Location, Pricing, Consumer Services, Store Design and Display, and Communication Mix) on purchasing decisions consumers in DM Baru Swalayan Bantul both partially and simultaneously. The object in this study is DM Baru Swalayan Bantul. This research was conducted by distributing questionnaires to 100 respondents are DM Baru Swalayan consumers who have shopped at least 2x (twice) in March and April. Analyzer used to measure the effect of Retail Mix on purchasing decisions is linear regression analysis multiple. Based on the results of the research variable Product Diversity, Store Location, Pricing, Consumer Services, Store Design and Display, and Communication Mix effect simultaneously, this is indicated by the value significance less than 0.05 is 0,000 . While the variables are partial effect is the customer service variable (X4) with value significance 0.004 $<0.05$ and the Communication Mix variable (X6) with values significance of $0.009<0.05$.
\end{abstract}

Keywords: Product Diversity; Store Locations; Pricing; Services Consumer; Store Design and Display; Communication Mix; Decision Purchase.

\begin{tabular}{l}
\hline PENDAHULUAN \\
Perkembangan teknologi modern \\
memberikan dampak terhadap kehidupan \\
yang menjadi semakin lebih praktis, \\
cepat, dan ekonomis. Seiring dengan \\
perkembangan teknologi tersebut, \\
keberadaan bisnis ritel modern menjadi \\
semakin penting karena adanya \\
pergeseran pola belanja masyarakat yang \\
lebih suka berbelanja di pasar ritel modern \\
seperti minimarket, supermarket atau \\
hipermarket. Masyarakat menjadi lebih \\
gemar untuk berbelanja di pasar ritel \\
modern dimana masyarakat bisa \\
mendapatkan kepraktisan dan kecepatan \\
dalam berbelanja. pola belanja tersebut \\
Pergeseran pola \\
disebabkan karena konsumen saat ini
\end{tabular}

semakin menginginkan kenyamanan dalam berbelanja, kepastian harga, pelayanan yang memuaskan, tersedianya kelengkapan produk yang berkualitas, lokasi yang strategis serta promosi yang menarik minat beli. Hal tersebut inilah yang kemudian menyebabkan industri ritel modern berkembang sangat cepat.

Di Indonesia, saat ini pertumbuhan usaha ritel atau eceran sangat pesat. Seiring dengan pesatnya perkembangan usaha ritel ini, maka persaingan di bidang pemasaran ritel atau eceran pun semakin meningkat. Dalam periode tahun 2007-2012, jumlah gerai ritel modern di Indonesia mengalami pertumbuhan rata-rata $17,57 \%$ per tahun. Pada tahun 2007, jumlah usaha ritel di Indonesia masih sebanyak 10.365 gerai, kemudian pada tahun 2011 mencapai 
18.152 gerai tersebar di hampir seluruh kota di Indonesia. Pertumbuhan jumlah gerai tersebut tentu saja diikuti dengan pertumbuhan penjualan. Menurut Asosiasi Perusahaan Ritel Indonesia (Aprindo), pertumbuhan bisnis ritel di Indonesia antara $10 \%-15 \%$ per tahun. Penjualan ritel pada tahun 2006 masih sebesar Rp49 triliun, dan melesat hingga mencapai Rp120 triliun pada tahun 2011. Sedangkan pada tahun 2012, pertumbuhan ritel diperkirakan masih sama, yaitu 10\%-15\%, atau mencapai Rp138 triliun (Marketing, 2013).

Masyarakat sekarang gemar sekali untuk berbelanja di Supermarket terdekat daripada harus berbelanja di pasar ataupun toko kelontong. Peluang tersebut kemudian banyak dilihat oleh para pengusaha yang ada. Para pengusaha mulai banyak membuka gerai-gerainya di kota sampai ke pelosok guna untuk memenuhi kebutuhan masyarakat yang kian meningkat.

Perkembangan tersebut berpengaruh terhadap setiap kota di Daerah Istimewa Yogyakarta, Khususnya Kota Bantul yang saat ini dipenuhi dengan banyaknya bangunan-bangunan ruko (rumah toko) sehingga diseluruh pelosok Yogyakarta tidak menutup kemungkinan kemudahan bagi konsumen untuk dapat memenuhi kebutuhannya sehari-hari yang sudah tersedia di tempat perbelanjaan ini. Kehadiran bisnis ritel modern yang semakin marak di Bantul saat ini ditandai dengan banyaknya berdiri supermarketsupermarket yang tersebar diberbagai tempat, sehubungan dengan hal tersebut supermarket yang ada di Bantul harus bersaing ketat dalam usahanya untuk dapat menguasai pangsa pasar yang ada. Syarat yang harus dipenuhi oleh perusahaan agar dapat sukses dalam persaingan ini adalah berusaha mencapai tujuan untuk menciptakan dan mempertahankan pelanggan. Sekarang lingkungan merupakan faktor eksternal yang sangat penting yang dapat mempengaruhi seorang konsumen dalam menentukan pilihan untuk membeli produk maupun jasa di tempat tertentu. Aspek kepuasan menjadi sangat penting sebagai salah satu pendorong bagi konsumen untuk berbelanja kembali disuatu tempat.

Supermarket adalah bentuk ritel bisnis modern yang menganut operasi swalayan, volume barang tinggi, laba sedikit dan biaya rendah. Bisnis retailing ini mengkhususkan diri dalam menawarkan jenis produk makanan dan minuman serta barang-barang untuk perawatan rumah tangga.

Supermarket merupakan sarana berbelanja bagi konsumen. Ciri khusus dari supermarket adalah barang - barang yang ditawarkan disusun pada rak - rak terbuka, konsumen bisa merasakan kepuasan untuk memilih sendiri barang -barang yang dibutuhkan sesuai dengan keinginannya, kemudian membawa ke kassa. Supermarket, atau usaha eceran, biasanya langsung menjual produk mereka kepada pemakai akhir. Kaitan dengan, dapat dikatakan dengan tempat yang dituju konsumen untuk memperoleh suatu produk adalah store, yang memiliki bentuk, luas, tipe, dan konsep yang beraneka ragam.

DM Baru Swalayan Bantul merupakan salah satu toko pengecer yang terdapat di wilayah Bantul dimana supermarket ini menyediakan berbagai kebutuhan pokok maupun kebutuhan lainnya yang diperlukan oleh masyarakat. Dalam aktivitas operasionalnya supermarket ini mencoba menghadirkan produk yang menjadi kebutuhan para konsumennya, antara lain menawarkan produkproduk dengan harga murah, kenyamanan berbelanja atau hanya sekedar kunjungan dan lain-lain. Ini memungkinkan adanya perjuangan yang keras dalam mempertahankan keberadaannya dari sekian banyak usaha ritel di Indonesia serta di Kota Bantul pada khususnya.

Selain DM Baru Swalayan Bantul, perkembangan minimarket di sekitar 
kawasan yang menjadi area persaingnya dalam bidang ritel modern yaitu Alfamart, Indomaret, dan minimarket lainnya yang memungkinkan dapat menjadi rival yang kuat dalam bidang bisnis retail ini . Untuk dapat bersaing dengan para pesaing tersebut harus memiliki strategi yang matang dan harus dapat memenuhi serta memuaskan kebutuhan para pelanggannya. Dengan strategi yang tepat, hal tersebut kemudian akan mempengaruhi keputusan para pelanggannya untuk melakukan pembelian di DM Baru Swalayan Bantul tersebut.

Dari tahun ke tahun DM Baru Swalayan Bantul menunjukan keeksistensiannya dengan bukti bahwa adanya banyak pesaing sejenis dibidang retail tapi supermarket ini tetap saja banyak diminati oleh masyarakat semua kalangan. DM Baru Swalayan kini telah memiliki 5 cabang swalayan yang tersebar di beberapa wilayah di Bantul, yaitu DM Baru 1 terletak di jalan pleret Km.4 No.6 Bantul, DM Baru 2 terletak di Jl.Wonosari Km.10 Sampakan Bantul, DM Baru 3 terletak di Jl. Imogiri timur Km. 7,5 Grojokan Bantul, DM Baru 4 terletak di Jl. Imogiri Barat Km.8 Bantul, dan DM Baru 6 terletak di Jl. Parangtritis Km. 10 Gabusan Bantul. Manajemen yang baik diterapkan oleh DM Baru Swalayan ini sehingga tetap diminati oleh masyarakat umum tersebut. Memang dalam supermarket ini harga yang ditetapkan relatif lebih murah dan terjangkau dibandingkan dengan pesaing sekitar yang ada, selain itu juga penerapan strategi yang tepat menjadi sebab dari keeksistensian supermarket ini dalam beberapa tahun.

Supermarket saat ini telah menerapkan strategi retail mix yang terdiri dari customer service (pelayanan konsumen), store design \& display (desain dan tampilan toko), communication mix, location (lokasi), merchandise assortment (keberagaman produk), dan pricing (penetapan harga). Hal ini merupakan strategi yang saling berhubungan untuk dapat mempengaruhi keputusan pembelian. Di DM Baru Swalayan sendiri faktor ini sudah sangat terlihat dan sudah diterapkan. Jika penerapan strategi-strategi tersebut telah baik dan sesuai dengan keinginan pelanggan, maka pelanggan tidak akan segan-segan untuk melakukan pembelian.

Pada ritel modern seperti, penerapan strategi retail mix diduga memiliki pengaruh yang besar terhadap keputusan pembelian pelanggan, sehingga supermarket kemudian dapat menjadi salah satu supermarket yang dicari dan dapat bersaing dengan para kompetitornya. Oleh karena itu, peneliti merasa perlu melakukan penelitian ini sehingga dapat diketahui bagaimana pengaruh retail mix terhadap keputusan pembelian di toko ritel modern seperti DM Baru Swalayan Bantul ini.

\section{REVIEW LITERATUR DAN HIPOTESIS}

\section{Landasan Teori}

1. Lokasi

Menurut Ma'ruf (2006)
menyatakan bahwa lokasi adalah
faktor yang sangat penting dalam
bauran pemasaran ritel (retail marketing
mix). Pada lokasi yang tepat, sebuah
gerai akan lebih sukses dibandingkan
gerai lainnya yang berlokasi kurang
strategis, meskipun keduanya menjual
produk yang sama, oleh pramuniaga
yang sama banyak dan terampil, dan
sama-sama punya setting/ambience
yang bagus.

2. Keberagaman Produk

Keberagaman produk adalah kegiatan yang dilakukan oleh perusahaan/peritel dalam hal pengadaan barang sesuai dengan bisnisnya dengan ragam/produk yang bermacam-macam untuk memenuhi kebutuhan konsumen. 
3. Harga

Menurut Kotler (2012) menyatakan bahwa harga adalah salah satu elemen bauran pemasaran yang menghasilkan pendapatan; elemen lain menghasilkan biaya.

4. Pelayanan Konsumen

$$
\text { Menurut Ma'ruf (2006) }
$$
menyatakan bahwa retail service bertujuan memfasilitasi para pembeli saat mereka berbelanja di gerai. Halhal yang dapat memfasilitasi para pembeli terdiri atas layanan pelanggan, personal selling, layanan transaksi berupa cara pembayaran yang mudah, layanan keuangan berupa penjualan dengan kredit dan fasilitas-fasilitas seperti contoh toilet, tempat mengganti pakaian bayi, food court, telepon umum dan sarana parkir.

5. Desain dan Tampilan Toko

Levy (2009) menyatakan tujuan utama dari desain toko adalah untuk menerapkan strategi pengecer. Desain harus konsisten dan dapat memperkuat strategi retail dengan memenuhi kebutuhan dari target pasar serta membangun keunggulan kompetitif yang berkelanjutan.

\section{Communication Mix}

Menurut Ma'ruf (2006), menyatakan bahwa communication mix merupakan kombinasi dari beberapa unsur promosi, yang lazimnya adalah iklan, sales promotion, personal selling, publisitas, dan atmosfer dalam gerai.

7. Keputusan Pembelian

Menurut Tjiptono (2008) keputusan pembelian adalah sebuah proses dimana konsumen mengenal masalahnya, mencari informasi mengenai produk/merek tertentu dan mengevaluasi seberapa baik masingmasing alternatif tersebut dapat memecahkan masalahnya, yang kemudian mengarah ke keputusan pembelian.

\section{Penelitian Terdahulu}

Peneltian Adji (2013) meneliti tentang Pengaruh Retail Mix Terhadap Keputusan pembelian mahasiswa UK Putra di Circle K Siwalankerto Surabaya. Dari hasil penelitian dapat disimpulkan bahwa variabel independen secara bersama-sama (simultan) berpengaruh signifikan terhadap variabel terikat yaitu Keputusan Pembelian (Y) di Circle K Siwalankerto Surabaya. Dan dari penelitian ini menunjukkan bahwa variabel bebas masing-masing menghasilkan nilai signifikansi $\mathrm{t}$ hitung yang lebih kecil dari $0.05(\alpha=5 \%)$ yaitu 0.002 untuk X1, 0.004 untuk X2, 0.034 untuk X3, 0.024 untuk X4, 0.004 untuk X5 dan 0.003 untuk X6. Maka dapat disimpulkan bahwa secara parsial masingmasing variabel akan memiliki pengaruh yang signifikan terhadap Keputusan Pembelian dan meningkatkan Keputusan Pembelian pelanggan di Circle K Siwalankerto Surabaya secara nyata. Dari hasil penelitain ini dapat disimpulkan bahwa variabel dalam Retail mix (Merchandise assortment, Lokasi, Harga, Pelayanan konsumen, Desain dan Tampilan Toko, dan Communication Mix) dapat diuji kembali, karena besar peran variabel tersebut terhadap keputusan pembelian.

Penelitian yang dilakukan oleh Salim (2013) yang meneliti tentang Analisa Pengaruh Retail Mix Terhadap Keputusan pembeian konsumen dikampoeng Roti Ngiden Surabaya. Dari penelitian tersebut didapatkan hasil bahwa variabel merchandise assortment, location, price, promotional mix, customer service, dan store design and display berpengaruh signifikan secara simultan dan parsial terhadap keputusan pembelian konsumen di Kampoeng Roti Nginden Surabaya. Dalam penelitain tersebut terdapat Terdapat satu variabel yang berpengaruh paling dominan 
terhadap keputusan pembelian konsumen di Kampoeng Roti Nginden Surabaya, yaitu variabel price. Dari hasil penelitain ini dapat disimpulkan bahwa variable dalam Retail mix (Merchandise assortment, Lokasi, Harga, Pelayanan konsumen, Desain dan Tampilan Toko, dan Communication Mix) dapat diuji kembali, karena besar peran variabel tersebut terhadap keputusan pembelian konsumen di kampoeng Roti Ngiden Surabaya.

\section{Hipotesis}

H1: Merchandise assortment / keberagaman produk mempunyai pengaruh terhadap keputusan pembelian.

H2: Lokasi Toko mempunyai pengaruh terhadap keputusan pembelian.

H3: Harga mempunyai pengaruh terhadap keputusan pembelian.

H4: Pelayanan konsumen mempunyai pengaruh terhadap keputusan pembelian.

H5: Desain dan Tampilan Toko mempunyai pengaruh terhadap keputusan pembelian.

H6: Communication Mix mempunyai pengaruh terhadap keputusan pembelian.

H7: Retail mix (Merchandise assortment, Lokasi, Harga, Pelayanan konsumen, Desain dan Tampilan Toko, dan Communication Mix) secara simultan berpengaruh terhadap keputusan pembelian.

\section{METODE PENELITIAN}

\section{Populasi dan Sampel}

Menurut Aligafari

menyatakan bahwa populasi adalah kumpulan dari semua anggota yang diteliti. Sedangkan menurut Sugiyono
(2010) menyatakan bahwa populasi adalah wilayah generalisasi yang terdiri atas: obyek/subyek yang mempunyai kualitas dan karakteristik tertentu yang ditetapkan oleh peneliti untuk dipelajari dan kemudian ditarik kesimpulan.

Populasi bukan hanya orang, tetapi juga obyek dan benda-benda alam yang lain. Populasi juga bukan sekedar jumlah yang ada pada obyek/subyek yang dipelajari, tetapi meliputi seluruh karakteristik/sifat yang dimiliki oleh subyek atau obyek itu.

Dari teori-teori diatas dapat ditarik kesimpulan bahwa populasi yaitu kumpulan dari semua anggota atau wilayah generalisasi dari obyek yang memiliki kualitas atau karakteristik yang dicari oleh peneliti untuk dipelajari peneliti dan kemudian dapat ditarik kesimpulan. Sehingga populasi dalam penelitian ini adalah seluruh konsumen DM Baru Swalayan Bantul.

Data yang digunakan untuk membuat penafsiran karakteristik suatu objek penelitian tidak harus melibatkan semua anggota dari objek tersebut, terutama objek yang anggotanya besar sekali dan letaknya tersebar. Penelitian yang menggunakan seluruh anggota objek yang diteliti membutuhkan banyak biaya, waktu, dan memerlukan banyak tenaga ahli.

Menurut Algifari (2013) menyatakan bahwa sampel adalah kumpulan dari sebagian anggota obyek yang diteliti. Menurut Sugiyono (2010) menyatakan bahwa sampel adalah bagian dari jumlah dan karakteristik yang dimiliki oleh populasi tersebut. Bila populasi besar, dan peneliti tidak mungkin mempelajari semua yang ada pada populasi, misalnya karena keterbatasan dana, tenaga dan waktu, maka peneliti dapat menggunakan sampel yang diambil dari populasi itu. Kesimpulanya akan dapat diberlakukan untuk populasi. Untuk itu sampel yang diambil dari populasi harus benar-benar representative / mewakili. 
Dari teori-teori di atas dapat disimpulkan bahwa sampel adalah sebagian dari populasi atau sebagian dari anggota dan karakteristik dari obyek atau populasi yang diteliti. Sampel dalam penelitian ini adalah Konsumen DM Swalayan yang melakukan pembelian di DM Baru Swalayan dalam 2 bulan terakhir (Maret dan April).

\section{Definisi Operasional}

1. Variabel Independen

Menurut Sugiyono (2010)

menyatakan bahwa variabel ini sering disebut sebagai variabel stimulus, atau predictor. Dalam bahasa Indonesia sering disebut sebagai variabel bebas. Variabel bebas adalah merupakan variabel yang mempengaruhi atau menjadi sebab perubahannya atau timbulnya variabel dependen (terikat). Dalam penelitian ini variabel independennya yaitu: Keberagaman produk, Lokasi, Penetapan Harga, Desain dan tampilan toko, Pelayanan konsumen, dan Communiation Mix.

2. Variabel Dependen

Menurut Sugiyono

menyatakan bahwa Variabel dependen adalah variabel yang dipengaruhi atau yang menjadi akibat, karena adanya variabel bebas.Variabel ini seing disebut dengan variabel output, kriteria, atau konsekuen. Variabel dependen dalam penelitian ini yaitu: Keputusan Pembelian.

\section{Uji Instrumen}

1. Uji Validitas

Menurut Adhilla (2013) menyatakan bahwa uji validitas digunakan untuk mengukur sah atau tidaknya suatu kuesioner. Menurut Sugiyono (2010:172) menyatakan bahwa hasil penelitian yang valid bila terdapat kesamaan antara data yang terkumpul dengan data yang sesungguhnya terjadi pada obyek yang diteliti. Sedangkan menurut Adhilla (2013) menyatakan bahwa suatu kuesioner dikatakan valid jika pertanyaan pada kuesioner mampu untuk mengungkapkan sesuatu yang akan diukur apakah pertanyaan dalam kuesioner yang sudah kita buat betul-betul dapat mengukur apa yang hendak kita ukur. Menurut Adhilla (2013) menyatakan bahwa mengukur validitas dapat dilakukan dengan cara melakukan korelasi bivariate antara masing-masing skor indicator dengan total skor konstruk. Dalam hal ini penelitian akan menggunakan SPSS versi 23.

\section{Uji Reliabilitas}

Menurut Adhilla (2013) menyatakan bawha reliabilitas sebenarnya adalah alat untuk mengukur suatu kuesioner yang merupakan indikator dari variabel atau konstruk. Suatu kuesioner dikatakan reliabelatau handal jika jawaban sesorang terhadap penyataan adalah konsisten atau stabil dari waktu ke waktu. Menurut Adhilla (2013) menyatakan bahwa pengukuran reliabilitas dapat dilakukan dengan dua cara, yaitu: Repeated measure (pengukuran ulang) dan One shot (pengukuran sekali saja). Dalam penelitian ini dalam mengukur reliabilitas dengan one shot (sekali saja), disini pengukurannya hanya sekali dan kemudian hasilnya dibandingkan dengan pertanyaan lain atau mengukur korelasi antar jawaban pertanyaan. Dalam penelitian ini menggunkan SPSS dengan uji statistic Cronbanch Alpha $(\alpha)$. Suatu konstruk atau variabel dikatakan reliabel jika memberikan nilai Cronbach Alpha > 0.60 . 
Teknik Analisis Data

1. Analisis Regresi Berganda

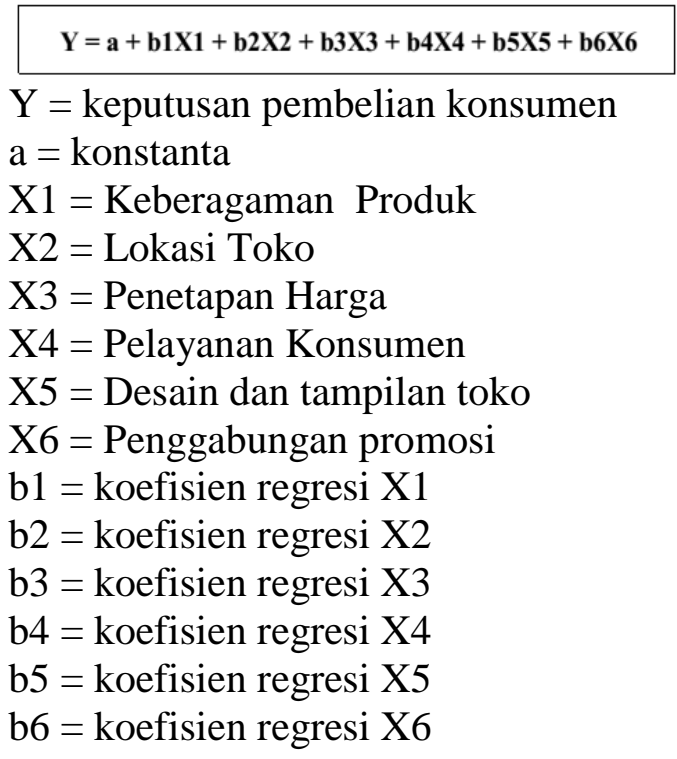

\section{Uji Hipotesis}

1. Uji Parsial (Uji T)

Dalam penelitian ini Uji Parsial (Uji T) dilakukan dengan SPSS. Menurut Adhilla (2013) menyatakan bahwa uji $t$ digunakan untuk mengetahui perbedaan nilai dari ratarata populasi dengan nilai ratarata sampel yang digunakan sebagai pembanding.

Kriteria penerimaan $\mathrm{Ha}$ atau penolakan $\mathrm{H} 0$ yaitu:

Jika nilai signifikan $>0.05$ maka kesimpulannya menerima $\mathrm{H} 0$.

Jika nilai signifikan $<0.05$ maka kesimpulannya menerima $\mathrm{Ha}$.

2. Uji Simultan (Uji F)

Uji $F$ atau ANOVA (analysis of fariance) merupakan salah satu uji komparatif yang digunakan untuk menguji perbedaan rata-rata data pada lebih dari dua kelompok (Adhilla, 2013).

\section{Uji Koefisien Determinasi}

Koefisien determinasi dapat digunakan sebagai petunjuk untuk mengetahui sejauh mana variabel independen dapat menjelaskan variasi variabel dependen. Besarnya koefisien determinasi adalah kuadrat dari koefisien korelasi. Misalnya suatu persamaan regresi mempunyai koefisien korelasi (r)-nya adalah 0,9 atau 90\% maka besarnya koefisien determinasi (r2) persamaan regresi tersebut adalah 0,81 atau $81 \%$, sedangkan sisanya $19 \%$ dijelaskan (dipengaruhi) oleh variabel lain diluar persamaan regresi (model) tersebut (Algifari, 2013).

\section{HASIL PENELITIAN DAN PEMBAHASAN}

\section{Hasil Analisis Responden}

Karakteristik Responden Berdasarkan Jenis Kelamin

\begin{tabular}{|l|l|l|}
\hline Jenis Kelamin & Frekuensi (Orang) & Frekuensi (\%) \\
\hline Laki-Laki & 31 & $31 \%$ \\
\hline Perempuan & 69 & $69 \%$ \\
\hline Jumlah & 100 & $100 \%$ \\
\hline
\end{tabular}

Berdasarkan tabel yakni deskripsi identitas responden berdasarkan jenis kelamin, menunjukkan bahwa responden yang berjenis kelamin laki-laki sebesar orang $31 \%$ dan yang berjenis kelamin perempuan sebesar orang atau 69\%. Dari angka tersebut menggambarkan bahwa konsumen yang mengunjungi DM Baru Swalayan Bantul masih di dominasi perempuan. Ini di karenakan konsumen perempuan lebih memilih menjadikan DM Baru Swalayan Bantul sebagai tempat belanja untuk kebutuhan sehari-hari dalam berumah tangga.

Karakteristik Responden Berdasarkan Usia

\begin{tabular}{|c|c|c|}
\hline Usia (Tahun) & Frekuensi (Orang) & Persentase (\%) \\
\hline$<20$ & 1 & $\mathbf{1} \%$ \\
\hline $20-25$ & $\mathbf{2 4}$ & $\mathbf{2 4 \%}$ \\
\hline $26-30$ & 39 & $39 \%$ \\
\hline $31-40$ & $\mathbf{2 0}$ & $\mathbf{2 0} \%$ \\
\hline$>40$ & 16 & $16 \%$ \\
\hline Jumlah & 100 & $\mathbf{1 0 0} \%$ \\
\hline
\end{tabular}

Dari tabel menunjukkan bahwa dari 100 orang yang dijadikan sampel dalam 
penelitian ini, responden yang berumur 26-30 tahun yakni sebesar 39 orang atau $39 \%$, hal ini dapat disimpulkan bahwa sebagian besar pelanggan atau konsumen yang membeli produk adalah konsumen yang berumur antara 26-30 tahun yang notabennya merupakan golongan Ibu Rumah Tangga.

Karakteristik Responden Berdasarkan Pekerjaan

\begin{tabular}{|l|l|l|}
\hline Pekerjaan & Frekuensi (Orang) & Persentase (\%) \\
\hline Pelajar/Mahasiswa & 7 & $7 \%$ \\
\hline Pegawai Swasta & 19 & $19 \%$ \\
\hline Pegawai Negeri Sipil & 13 & $13 \%$ \\
\hline Buruh & 19 & $19 \%$ \\
\hline Ibu Rumah Tangga & 31 & $31 \%$ \\
\hline Wiraswasta & 11 & $11 \%$ \\
\hline Jumlah & 100 & $100 \%$ \\
\hline
\end{tabular}

Tabel menunjukkan bahwa dari 100 orang responden yang diteliti sebanyak $29 \%$ golongan ibu rumah tangga mendominasi konsumen yang datang di DM Baru Swalayan, sedangkan sisanya didominasi oleh pegawai swasta, PNS, dan Buruh. Ibu Rumah Tangga lebih mendominasi karena mengingat bahwa DM Baru Swalayan adalah tempat belanja yang berdekatan dengan rumah dan dianggap lebih lengkap untuk pemenuhan kebutuhan sehari-hari.

\section{Hasil Penelitian}

1. Hasil Uji Validitas

Hasil Uji Validitas Instrumen

\begin{tabular}{|c|c|c|c|c|}
\hline $\mathrm{NO}$ & Variabel & $\begin{array}{c}\text { Item } \\
\text { pertanyaan }\end{array}$ & $\begin{array}{c}\mathrm{R} \\
\text { Hitung }\end{array}$ & $\begin{array}{c}\text { Keterangan } \\
\text { (R Hitung }>\text { R } \\
\text { Tabel }=\text { Valid) } \\
\text { R Tabel }=0,374\end{array}$ \\
\hline 1 & Keberagaman Produk & $\begin{array}{l}\text { Q1 } \\
\text { Q2 } \\
\text { Q3 }\end{array}$ & $\begin{array}{l}0,598 \\
0,350 \\
0,540\end{array}$ & $\begin{array}{c}\text { Valid } \\
\text { Tidak Valid } \\
\text { Valid }\end{array}$ \\
\hline 2 & Lokasi Toko & $\begin{array}{l}\text { Q4 } \\
\text { Q5 } \\
\text { Q6 } \\
\text { Q7 }\end{array}$ & $\begin{array}{l}0,705 \\
0,808 \\
0,672 \\
0,466\end{array}$ & $\begin{array}{l}\text { Valid } \\
\text { Valid } \\
\text { Valid } \\
\text { Valid }\end{array}$ \\
\hline 3 & Penetapan Harga & $\begin{array}{l}\text { Q8 } \\
\text { Q9 } \\
\text { Q10 }\end{array}$ & $\begin{array}{l}0,625 \\
0,630 \\
0,538\end{array}$ & $\begin{array}{l}\text { Valid } \\
\text { Valid } \\
\text { Valid }\end{array}$ \\
\hline 4 & Pelayanan Konsumen & $\begin{array}{l}\text { Q11 } \\
\text { Q12 } \\
\text { Q13 } \\
\text { Q14 } \\
\text { Q15 }\end{array}$ & $\begin{array}{l}0,633 \\
0,590 \\
0,452 \\
0,838 \\
0,647\end{array}$ & $\begin{array}{l}\text { Valid } \\
\text { Valid } \\
\text { Valid } \\
\text { Valid } \\
\text { Valid }\end{array}$ \\
\hline 5 & $\begin{array}{l}\text { Desain dan Tampilan } \\
\text { Toko }\end{array}$ & $\begin{array}{l}\text { Q16 } \\
\text { Q17 } \\
\text { Q18 } \\
\text { Q19 }\end{array}$ & $\begin{array}{l}0,799 \\
0,789 \\
0,724 \\
0,579\end{array}$ & $\begin{array}{l}\text { Valid } \\
\text { Valid } \\
\text { Valid } \\
\text { Valid }\end{array}$ \\
\hline 6 & $\begin{array}{l}\text { Communication } \\
\text { Mix/Penggabungan } \\
\text { Promosi }\end{array}$ & $\begin{array}{l}\text { Q20 } \\
\text { Q21 } \\
\text { Q22 }\end{array}$ & $\begin{array}{l}0,534 \\
0,514 \\
0,727\end{array}$ & $\begin{array}{l}\text { Valid } \\
\text { Valid } \\
\text { Valid }\end{array}$ \\
\hline 7 & Keputusan Pembelian & $\begin{array}{l}\text { Q23 } \\
\text { Q24 } \\
\text { Q25 }\end{array}$ & $\begin{array}{l}0,574 \\
0,634 \\
0,758 \\
\end{array}$ & $\begin{array}{l}\text { Valid } \\
\text { Valid } \\
\text { Valid }\end{array}$ \\
\hline
\end{tabular}

Tabel di atas menunjukan bahwa koefisien korelasi pada indikator Q2 menunjukan nilai sebesar 0,350 , dimana nilai tersebut lebih kecil dari 0,374 (R Tabel) sehingga indikator dalam penelitian ini dinyatakan tidak valid, sehingga untuk itu dalam penelitian ini indikator tersebut akan dihilangkan dalam daftar pertanyaan yang akan saya ajukan pada responden selanjutnya. Sedangkan untuk indikator lainnya menunjukan nilai lebih besar dari 0,374 (R Tabel), sehingga dapat disimpulkan bahwa indikato-indikator tersebut dalam penelitian ini dinyatakan valid.

2. Hasil Uji Reliabilitas

Hasil Uji Reabilitas Instrumen

\begin{tabular}{|c|c|c|c|}
\hline Variabel & $\begin{array}{c}\text { Cronbach's } \\
\text { Alpha }\end{array}$ & $\begin{array}{c}\text { Cronbach's Alpha Based } \\
\text { on Standardized Items }\end{array}$ & N of Items \\
\hline Keberagaman Produk & .669 & .665 & 3 \\
\hline Lokasi Toko & .827 & .825 & 4 \\
\hline Penetapan Harga & .764 & .766 & 3 \\
\hline Pelayanan Konsumen & .821 & .822 & 5 \\
\hline Desan dan Tampilan Toko & .864 & .870 & 4 \\
\hline Penggabungan Promosi & .744 & .759 & 3 \\
\hline Keputusan Pembelian & .805 & .806 & 3 \\
\hline
\end{tabular}

Berdasarkan Tabel Diatas semua variabel memiliki Cronbach Alpha 
lebih besar dari 0,60, sehingga dapat dikatakan bahwa masing-masing variabeldari kuesioner adalah reliabel sehingga untuk selanjutnya masingmasing indikator layak digunakan sebagai alat ukur.

\section{Hasil Uji Regresi Linier Berganda} Koefisien Regresi Berganda

\begin{tabular}{|c|c|c|}
\hline \multirow{2}{*}{ Model } & \multicolumn{2}{|c|}{$\begin{array}{l}\text { Unstandardized } \\
\text { Coefficients }\end{array}$} \\
\hline & B & Std. Error \\
\hline \multirow{3}{*}{$\begin{array}{ll}1 & \text { (Constant) } \\
& \text { KeberagamanProduk }\end{array}$} & 1,550 & ,503 \\
\hline & & \\
\hline & ,156 & , 108 \\
\hline LokasiToko & ,050 & ,098 \\
\hline PenetapanHarga &,- 240 & ,179 \\
\hline \multirow[t]{2}{*}{ PelayananKonsumen } & & \\
\hline & ,510 & ,174 \\
\hline \multirow[t]{2}{*}{ DesainTampilanToko } & & \\
\hline &,- 171 &, 178 \\
\hline \multirow{2}{*}{ PenggabunganPromosi } & & \\
\hline &, 370 & 139 \\
\hline
\end{tabular}

Persamaan regresi berganda tersebut menunjukkan arah masingmasing variabel bebas terhadap variabel terikatnya. Persamaan regresi berganda tersebut dapat diuraikan sebagai berikut:

$\beta 1=+0,156$, menunjukan bahwa apabila keberagaman produk yang ditawarkan banyak dan ketersediaan produk/produk jarang kosong dan mampu memenuhi kebutuhan konsumen maka akan lebih meyakinkan konsumen untuk melakukan keputusan pembelian pada DM Baru Swalayan Bantul.

$\beta 2=+0,050$, menunjukan bahwa apabila lokasi toko strategis, mudah untuk dijangkau, mudah juga untuk dilihat, dan tersedia lahan parkir yang memadai untuk kendaraan konsumen maka akan lebih meyakinkan konsumen untuk melakukan keputusan pembelian pada DM Baru Swalayan Bantul. $\beta 3=-0,240$, menunjukan bahwa apabila harga yang ditetapkan terjangkau, sesuai dengan kualitas produk, dan harga dapat bersaing dengan competitor/pesaing maka tidak akan lebih meyakinkan (tidak berhubungan dengan) konsumen untuk melakukan keputusan pembelian pada DM Baru Swalayan Bantul.

$\beta 4=+0,510$, menunjukan bahwa apabila Kebersihan didalam toko yang terawat, karyawan yang ramah saat melayani konsumen, kemudahan dalam pembayaran (cash, kartu kredit/debit), karyawan mampu menangani keluhan dari pelanggan, dan karyawan mampu menyampaikan informasi dengan jelas maka akan lebih meyakinkan konsumen untuk melakukan keputusan pembelian pada DM Baru Swalayan Bantul.

$\beta 5=-0,171$, menunjukan bahwa apabila Kondisi toko yang terawat, penempatan grafis dalam memberikan informasi produk, penempatan $\mathrm{rak} / \mathrm{meja}$ yang rapi, penempatan produk yang rapi sehingga mudah untuk dicari maka tidak akan lebih meyakinkan (tidak berhubungan dengan) konsumen untuk melakukan keputusan pembelian pada DM Baru Swalayan Bantul.

$\beta 6=+0,370$, menunjukan bahwa apabila tersedianya produk-produk yang sedang promosi, tersedianya sales/karyawan yang memberikan penjelasan terhadap produk tertentu, dan adanya iklan yang dipasang ditoko/sekitarnya maka akan lebih meyakinkan konsumen untuk melakukan keputusan pembelian pada DM Baru Swalayan Bantul. 
4. Hasil Uji Parsial (Uji T)

\begin{tabular}{|c|c|c|c|c|c|}
\hline \multirow[b]{2}{*}{ Model } & \multicolumn{2}{|c|}{$\begin{array}{c}\text { Unstandardized } \\
\text { Coefficients }\end{array}$} & \multirow{2}{*}{$\begin{array}{c}\text { Standardized } \\
\text { Coefficients } \\
\text { Beta } \\
\end{array}$} & \multirow[b]{2}{*}{$\mathrm{t}$} & \multirow[b]{2}{*}{ Sig. } \\
\hline & B & Std. Error & & & \\
\hline 1 (Constant) & 1,550 &, 503 & & 3,082 & ,003 \\
\hline KeberagamanProduk &, 156 & , 108 & 157 & 1,446 & 152 \\
\hline LokasiToko & ,050 & ,098 & ,057 &, 511 & 611 \\
\hline PenetapanHarga &,- 240 & 179 &,- 208 & $-1,346$ & 182 \\
\hline PelayananKonsumen &, 510 & , 174 & ,504 & 2,937 & ,004 \\
\hline DesainTampilanToko &,- 171 & ,178 &,- 156 &,- 961 & ,339 \\
\hline PenggabunganPromosi &, 370 & ,139 & ,352 & 2,659 & ,009 \\
\hline
\end{tabular}

1. Keberagaman Produk (X1)

Variabel Keberagaman Produk menunjukan signifikasi sebesar 0,152, > 0,05 maka menerima H0. Kemungkinan variabel ini tidak berpengaruh terhadap variabel $\mathrm{Y}$ karena apabila variabel ini saja yang diutamakan dan tidak digabungkan secara bersama-sama dengan variabel lain dalam retail mix maka variabel keberagaman produk tidak dapat berpengaruh, tetapi variabel akan berpengaruh terhadap keputusan Pembelian apabila digabungkan dan dioptimalkan dengan variabel lain dalam retail mix. Variabel ini juga mempunyai nilai positif (+) sehingga mempunyai pengaruh yang searah terhadap keputusan pembelian, yaitu semakin tinggi keberagaman produk maka akan semakin tinggi pula nilainya terhadap keputusan pembelian konsumen, begitu juga sebaliknya.

2. Variabel Lokasi Toko (X2)

Variabel Lokasi Toko menunjukan signifikasi sebesar $0,611>0.05$ maka menerima $\mathrm{H} 0$. Kemungkinan variabel ini tidak berpengaruh terhadap variabel $\mathrm{Y}$ karena apabila variabel ini saja yang diutamakan dan tidak digabungkan secara bersama-sama dengan variabel lain dalam retail mixmaka variabel Lokasi Toko tidak dapat berpengaruh, tetapi variabel akan berpengaruh terhadap keputusan Pembelian apabila digabungkan dan dioptimalkan dengan variabel lain dalam retail mix. Variabel ini juga mempunyai nilai positif (+) sehingga mempunyai pengaruh yang searah terhadap keputusan pembelian, yaitu semakin tinggi lokasi toko maka akan semakin tinggi pula nilainya terhadap keputusan pembelian konsumen, begitu juga sebaliknya.

3. Variabel Penetapan Harga (X3)

Variabel Penetapan Harga menunjukan signifikasi sebesar $0.182>0.05$ maka menerima H0. Kemungkinan variabel ini tidak berpengaruh terhadap variabelY karena apabila variabel ini saja yang diutamakan dan tidak digabungkan secara bersama-sama dengan variabel lain dalam retail mix maka variabel penetapan harga tidak dapat berpengaruh, tetapi variabel akan berpengaruh terhadap keputusan Pembelian apabila digabungkan dan dipotimalkan dengan variabel lain dalam retail mix. Variabel ini juga mempunyai nilai negatif (-) sehingga mempunyai pengaruh yang berlawanan terhadap keputusan pembelian, yaitu semakin tinggi penetapan harga maka akan semakin rendah nilainya terhadap keputusan pembelian konsumen, begitu juga sebaliknya.

4. Variabel Pelayanan Konsumen (X4) Variabel Pelayanan konsumen menunjukan signifikasi sebesar $0.004<0.05$ maka menerima Ha. Hal ini berarti bahwa pelayanan konsumen berpengaruh positif dan signifikan terhadap keputusan pembelian. Hasil penelitian ini mendukung hipotesis keempat yaitu bahwa Pelayanan konsumen mempunyai pengaruh terhadap keputusan pembelian. Variabel ini juga mempunyai nilai positif (+) sehingga mempunyai pengaruh yang 
searah terhadap keputusan pembelian, yaitu semakin tinggi pelayanan konsumen maka akan semakin tinggi pula nilainya terhadap keputusan pembelian konsumen, begitu juga sebaliknya. Hasil penelitian ini juga sesuai dengan penelitian yang dilakukan oleh Adji meneliti tentang "Pengaruh Retail Mix Terhadap Keputusan pembelian mahasiswa UK Putra di Circle K Siwalankerto Surabaya", hasil penelitian tersebut variabel Customer Service berpengaruh signifikan positif terhadap keputusan pembelian.

5. Variabel Desain dan Tampilan Toko (X5)

Toko menunjukan signifikasi sebesar $0.339>0.05$ maka menerima Ho. Kemungkinan variabel ini tidak berpengaruh terhadap variabel $\mathrm{Y}$ karena apabila variabel ini saja yang diutamakan dan tidak digabungkan secara bersama-sama dengan variabel lain dalam retail mix maka variabel desan dan tampilan toko tidak dapat berpengaruh, tetapi variabel akan berpengaruh terhadap keputusan Pembelian apabila digabungkan dan dipotimalkan dengan variabel lain dalam retail mix. Variabel ini juga mempunyai nilai negatif (-) sehingga mempunyai pengaruh yang berlawanan terhadap keputusan pembelian, yaitu semakin tinggi desain dan tampilan toko maka akan semakin rendah nilainya terhadap keputusan pembelian konsumen, begitu juga sebaliknya, dalam hal ini memungkinkan akan menimbulkan citra yang mahal apabila desain terlalu mewah dan tinggi.
6. Variabel Communication Mix (X6)

Variabel Communication Mix menunjukan signifikasi sebesar $0.009<0.05$ maka menerima Ha. Hal ini berarti bahwa Communication Mix berpengaruh positif dan signifikan terhadap keputusan pembelian. Variabel ini juga mempunyai nilai positif $(+)$ sehingga mempunyai pengaruh yang searah terhadap keputusan pembelian, yaitu semakin Communication Mix maka akan semakin tinggi pula nilainya terhadap keputusan pembelian konsumen, begitu juga sebaliknya. Hasil penelitian ini juga sesuai dengan penelitian yang dilakukan oleh Salim yang meneliti tentang "Analisa Pengaruh Retail Mix Terhadap Keputusan pembeian konsumen dikampoeng Roti Ngiden Surabaya", hasil penelitian tersebut variabel Promotional Mix berpengaruh signifikan positif terhadap keputusan pembelian.

\section{Hasil Uji Simultan (Uji F)}

Uji Simultan F

\begin{tabular}{|c|c|c|c|c|c|}
\hline Model & $\begin{array}{l}\text { Sum of } \\
\text { Squares }\end{array}$ & df & $\begin{array}{l}\text { Mean } \\
\text { Square }\end{array}$ & F & Sig. \\
\hline 1 Regression & 6,934 & 6 & 1,156 & \multirow[t]{3}{*}{7,892} & \multirow[t]{3}{*}{$.000^{\mathrm{b}}$} \\
\hline Residual & 13,619 & 93 & \multirow[t]{2}{*}{,146 } & & \\
\hline Total & 20,553 & 99 & & & \\
\hline
\end{tabular}

Berdasarkan hasil uji simultan dari tabel di atas ditunjukkan bahwa nilai signifikansi lebih kecil dari 0,05. Perhitungan tersebut menunjukkan bahwa variabel Keberagaman produk (X1), Lokasi toko (X2), Penetapan harga (X3), Pelayanan konsumen (X4), Desain dan Tampilan toko (X5), dan Communication Mix/Penggabungan promosi (X6) secara bersama-sama berpengaruh terhadap variabel keputusan pembelian (Y). 
6. Hasil Uji Koefisien Determinasi

Koefisien Determinasi

\begin{tabular}{|l|l|r|r|c|}
\hline Model & R & R Square & $\begin{array}{c}\text { Adjusted } \\
\text { R Square }\end{array}$ & $\begin{array}{c}\text { Std. Error of the } \\
\text { Estimate }\end{array}$ \\
\hline 1 & $.581^{\mathrm{a}}$ &, 337 &, 295 &, 38267 \\
\hline
\end{tabular}

Angka R Square adalah 0,337 (adalah pengkuadratan dari korelasi, atau 0,581 X 0,581 = 0,337). $\mathrm{R}$ Square atau bisa disebut dengan koefisien determinasi dalam hal ini berarti 33,7\% Keputusan Pembelian dapat dijelaskan oleh variabel Communication Mix, Keberagaman Produk, LokasiToko, Pelayanan Konsumen, Penetapan Harga, Desain Tampilan Toko. Sedangkan sisanya $(100 \%-33,3 \%=66,7 \%)$ dijelaskan oleh sebab-sebab lain yang memungkinkan dapat menjelaskan terhadap keputusan pemelian konsumen di DM Baru Swalayan Bantul.

\section{Pembahasan}

1. Keberagaman Produk

Variabel Keberagaman produk memperoleh hasil menerima $\mathrm{H} 0$, yaitu variabel keberagaman produk tidak berpengaruh terhadap keputusan pembelian di DM Baru Swalayan. Variabel ini tidak berpengaruh terhadap keputusan pembelian dimungkinkan swalayan modern saat ini rata-rata sudah mempunyai keberagaman produk yang dapat memenuhi kebutuhan masyarakat baik kebutuhan rumah tangga ataupun kebutuhan lainnya, sudah banyak swalayan yang menjual produk dengan beraneka ragam dan merek. Dengan banyaknya swalayan yang telah menjual produk dengan lengkap dan dapat dengan mudah untuk menemukan swalayan disetiap daerah khususnya Bantul, menimbulkan persepsi oleh masyarakat bahwa setiap swalayan sudah menjual produk untuk memenuhi kebutuhannya, sehingga keberagaman produk yang disediakan oleh DM Baru Swalayan tidak berpengaruh signifikan terhadap keputusan pembelian itu sendiri.

\section{Lokasi Toko}

Variabel Lokasi Toko

memperoleh hasil menerima $\mathrm{H} 0$, yaitu variabel Lokasi Toko tidak berpengaruh terhadap keputusan pembelian di DM Baru Swalayan. Variabel ini tidak berpengaruh terhadap keputusan pembelian dimungkinkan pada saat ini masyarakat pada umumnya telah memiliki kendaraan bermotor untuk melakukan kegiatan atau sekedar berbelanja khususnya, kendaraan tersebut dapat mempermudah untuk meningkatkan mobilitas masyarakat dalam menyelesaikan pekerjaannya. Masyarakat dapat berbelanja di swalayan dengen menggunakan kendaraan walaupun jaraknya dekat ataupun jauh, jadi pada umumnya lokasi toko tidak dipedulikan oleh masyarakat itu sendiri. Oleh karena itu Lokasi Toko tidak berpengaruh terhadap keputusan pembelian di DM Baru Swalayan.

3. Penetapan Harga

Variabel Penetapan Harga memperoleh hasil menerima $\mathrm{H} 0$, yaitu variabel Penetapan Harga tidak berpengaruh terhadap keputusan pembelian di DM Baru Swalayan. Variabel ini tidak berpengaruh terhadap keputusan pembelian dimungkinkan pada saat ini harga yang ditawarkan oleh banyak swalayan tidak berbeda jauh antara satu dengan yang lainnya, persaingan harga tidak begitu signifikan sehingga untuk konsumen sendiri tidak terlalu mempedulikan akan perbedaaan harga yang ada. Oleh sebab itu, Penetapan harga oleh DM Baru Swalayan tidak berpengaruh terhadap keputusan pembelian.

4. Pelayanan Konsumen

Variabel Pelayanan konsumen memperoleh hasil menerima $\mathrm{Ha}$, yaitu variabel Pelayanan konsumen berpengaruh terhadap keputusan 
pembelian di DM Baru Swalayan. DM Baru Swalayan memberikan pelayanan konsumen yang baik untuk memberikan pengaruh terhadap keputusan pembelian. Dalam hal ini dapat disimpulkan bahwa DM Baru Swalayan merupakan toko swalayan yang bersih, mempunyai karyawan yang ramah saat melayani, memberikan kemudahan pembayaran, mampu melayani keluhan konsumen, dan mampu memberikan informasi yang jelas terhadap apa yang dibutuhkan oleh konsumen. Dalam hal ini dapat terbukti bahwa pelayanan konsumen memberikan pengaruh terhadap keputusan pembelian sesuai dengan penelitian yang dilakukan oleh Adji meneliti tentang Pengaruh Retail Mix Terhadap Keputusan pembelian mahasiswa UK Putra di Circle K Siwalankerto Surabaya, dari penelitian tersebut pelayanan konsumen berpengaruh secara signifikan terhadap keputuan pembelian. Hasil dari penelitian ini juga mendukung teori yang dikemukakan oleh Ma'ruf (2006), menyatakan bahwa retail service bertujuan memfasilitasi para pembeli saat mereka berbelanja di gerai.

\section{Desain dan Tampilan Toko}

Variabel desain dan tampilan toko memperoleh hasil menerima $\mathrm{H} 0$, yaitu variabel desain dan tampilan toko tidak berpengaruh terhadap keputusan pembelian di DM Baru Swalayan. Variabel ini tidak berpengaruh terhadap keputusan pembelian dimungkinkan desain dan tampilan toko swalayan modern saat ini hampir mirip dan sudah memberikan kesan yang baik terhadap masyarakat sehingga dalam hal keputusan pembelian tidak memberikan pengaruh yang signifikan.

\section{Communication Mix}

Variabel Communication Mix memperoleh hasil menerima $\mathrm{Ha}$, yaitu variabel Communication Mix berpengaruh terhadap keputusan pembelian di DM Baru Swalayan. DM Baru Swalayan memberikan promosi yang baik terhadap konsumennya. DM Baru Swalayan selalu memberikan promosi dibeberapa produknya baik itu secara lamgsung maupun tidak langsung, dibagian depan toko juga selalu ada media promosi yang dimanfaatkan untuk menampilkan promosi yang sedang diberikan oleh toko. Di bagian dalam toko juga memberikan banyak promosi menarik untuk konsumen. Hasil ini juga sesuai dengan penelitian yang dilakukan oleh Salim yang meneliti tentang "Analisa Pengaruh Retail Mix Terhadap Keputusan pembeian konsumen dikampoeng Roti Ngiden Surabaya" dengan hasil bahwa Communication Mix memberikan pengaruh yang signifikan terhadap keputusan pembelian konsumen.

\section{KESIMPULAN DAN SARAN}

\section{Kesimpulan}

1. Berdasarkan hasil dari analisis regresi linier berganda menunjukkan bahwa Keberagaman Produk (X1), Lokasi Toko (X2), Penetapan Harga (X3), Pelayanan Konsumen (X4), Desain dan Tampilan Toko (X5), dan Communication Mix/Penggabungan Promosi (X6) mempunyai pengaruh terhadapat keputusan pembelian (Y) pada konsumen DM Baru Swalayan. Dari hasil perhitungan uji $\mathrm{F}$, dapat dilihat Signifikasi yang didapatkan lebih kecil dari 0,05 sehingga disimpulkan menerima $\mathrm{Ha}$, yang berbunyi Retail Mix (Keberagaman Produk, Lokasi Toko, Penetapan Harga, Pelayanan Konsumen, Desain dan Tampilan Toko, dan Communication Mix/Penggabungan Promosi secara simultan berpengaruh terhadap keputusan pembelian. Sehingga hipotesis yang mengatakan terdapat pengaruh yang signifikan 
secara simultan dari komponen retailing mix yang terdiri dari produk, harga, promosi, pelayanan pelanggan, suasana toko, dan lokasi terhadap keputusan pembelian pada konsumen DM Baru Swalayan diterima.

2. Berdasarkan hasil uji $\mathrm{T}$, variabel pelayanan konsumen (X4) dan Communication Mix /Penggabungan Promosi (X6) berpengaruh terhadap keputusan pembelian konsumen DM Baru Swalayan. Berdasarkan hasil penelitian ini toko dapat terus menjaga dan mempertahankan variabel ini untuk terus diperhatikan, sedangkan variabel lain dimungkinkan tidak berpengaruh karena Keberagaman Produk, Lokasi Toko, Penetapan Harga, Desain dan Tampilan Toko swalayanswalayan yang ada saat ini mayoritas hampir sama dan tidak ada yang begitu signifikan perbedaaannya dalam elemen tersebut sehingga tidak mempengaruhi keputusan pembelian konsumen.

3. Berdasarkan nilai koefisien determinasi menunjukkan nilai $\mathrm{R}$ Square sebesar 0,337 hal ini berari seluruh variabel turunan retailing mix mempunyai kontribusi secara bersama-sama sebesar $33,7 \%$ terhadap variabel terikat $(\mathrm{Y})$ yakni keputusan pembelian. Sisanya sebesar 66,3\% dipengaruhi oleh faktorfaktor lain yang tidak masuk dalam penelitian.

\section{Saran}

1. DM Baru Swalayan harus bisa mempertahankan variabel yang berpengaruh langsung terhadap keputusan pembelian konsumen, yaitu:
a. Variabel Pelayanan konsumen Perusahaan harus selalu menjaga kualitas pelayanan konsumen seperti mempertahankan toko yang bersih, mempunyai karyawan yang ramah saat melayani, memberikan kemudahan pembayaran, mampu melayani keluhan konsumen, dan mampu memberikan informasi yang jelas terhadap apa yang dibutuhkan oleh konsumen. Perusahaan harus memperhatikan variabel ini agar selalu memberikan kepuasan yang tinggi dan berpengaruh terhadap keputusan pembelian konsumen.

b. Variabel Communication Mix /Penggabungan PromosiFaktor ini sudah baik diterapkan oleh perusahaan, tetapi perusahaan juga tetap harus ingat untuk selalu menjaga kualitas faktor ini agar selalu berpengaruh terhadap keputusan pembelian. Faktor ini melibatkan bagaimana perusahaan melakukan promosi untuk di dalam toko ataupun di luar, yaitu seperti: selalu adanya promosi bagian depan toko yang terlihat jelas oleh konsumen, adanya promosi langsung di display product, adanya promosi sampel, ataupun adanya promosi di bagian Point of purchase (Meja kasir). Faktor ini salah satunya strategi yang harus dilakukan oleh perusahaan untuk mempertahankan dan menjaga kualitas dari perusahaan.

2. Variabel lain yang tidak berpengaruh diharapkan bisa diperhatikan oleh perusahaan mengingat saat ini banyak swalayan yang hampir sama dalam penerapan strategi. DM Baru Swalayan harus bisa meningkatkanstrategi dalam bersaing dan selalu memiliki tekad yang kuat agar bisa bertahan, karena kepuasan konsumen adalah terletak pada sejauh mana perusahaan bisa memberikan yang terbaik bagi konsumen sehingga perputaran barang dapat meningkat.

3. Sebaiknya pengelola DM Baru Swalayan tidak hanya melihat pengaruh dari retail mix yang ada, melainkan dapat melihat pengaruh dari faktorfaktor lainnya semacam marketing 
mix, promotional mix, positioningdan lain-lain nya. Dengan memperhatikan banyak unsur dalam marketing maka tingkat pelayanan yang diberikan akan semakin baik dan memberikan kepuasan lebih kepada konsumen.

4. Bagi peneliti lain menggunakan pembeli pertama dalam penelitian, dan lebih meperbanyak referensi dan, karena setiap lokasi atau objek penelitian mempunyai karakteristik yang berbeda, demikan hasil yang diperolehpun dapat berbeda pula.

\section{DAFTAR PUSTAKA}

Adhilla, Fitroh, dkk. (2013). Modul Praktikum Satistik 2. Yogyakarta: UAD.

Adhilla, Fitroh. (2013). Modul Praktikum analisis multivariate 1. Yogyakarta: UAD.

Algifari. (2013). Statistika deskriptif plus untuk ekonomi dan bisnis. Yogyakarta: UPP STIM YKPN.

Adji, Pricilia dan Dr. Hartono Subagio. (2013). "Pengaruh Retail Mix Terhadap Keputusan Pembelian Mahasiswa UK Petra Di Circle K Siwalankerto Surabaya". Jurusan Manajemen Pemasaran.

Kotler, Philip dan Kevin, Keller. (2012). Manajemen Pemasaran. Jilid 1. Jakarta: PT. Indeks Kelompok Gramedia.

Levy, Michael dan Weitz, Barton A. (2009). Retailing Management (7th Ed.). New York: McGraw-Hill Irwin.

Ma'ruf, Hendri. (2006). Pemasaran Ritel. Jakarta: PT. Gramedia Pustaka Utama.

Salim, Wira, dan Dr. Hartono Subagio. (2013). "Analisa Pengaruh Retail
Mix Terhadap Keputusan Pembelian Konsumen Di Kampoeng Roti Ngidem Surabaya". Jurusan Manajemen Pemasaran.

Sugiyono. (2010). Metode Peneltian Bisnis. Bandung: Alfabeta.

Tjiptono, Fandy. (2008). Strategi Pemasaran. Edisi kedua. Yogayakarta: Andi Offset. 